\title{
Critical Analysis of the Management System of Hazardous Solid Waste Generated in the City of Santos in the State of São Paulo
}

\author{
Ulysses Martins Moreira Filho and Pedro Luiz de Oliveira Costa Neto \\ Paulista University-UNIP, Pós-Graduate Program in Production Engineering, \\ Dr. Bacelar St. 1212, 04026-002, São Paulo - SP, Brazil \\ \{moreiraf, politeleia\}@uol.com.br
}

\begin{abstract}
The world is undergoing major transformations with significant social, political and economic changes. Science and technology have evolved much from the twentieth century, and the intensification of industrial activity has its production techniques increasingly sophisticated, multiplying physical territory, what unfortunately had a negative impact on the environment. The objective of this study is to perform a critical analysis of the current Integrated Solid Waste System in the city of Santos in, the Brazilian coast, focusing on hazardous waste, identifying opportunities for improvement. Representative sectors governances were heard through the application of a structured questionnaire based on three pillars: Environmental Education for the population, Communication System and Infrastructure offered by the municipal authority. The results show weakness in the system of management in relation to environmental education and communication system, as well as absence of the main timeline of actions to achieve the proposed results.
\end{abstract}

Keywords: Hazardous waste, Reverse Logistics, Management System.

\section{Introduction}

The Industrial Revolution, from about 1850, led to strong growth in world production consumption of goods, with emphasis on efficiency and effectiveness through the concepts advocated by the Classical School: Bureaucracy, Human Relations and Systems Thinking. These business schools saw the natural environment prevailed as a mechanic and deterministic thinking, nature being considered an obstacle to the development of society. Science and technology have evolved much within the twentieth century, and the intensification of industrial activity had its production techniques increasingly sophisticated, multiplying physical territory, which unfortunately had a negative impact on the environment [1]. For decades the process of environmental degradation increased, being believed that the economic growth by itself would provide the best conditions due to society. However, it was observed that uncontrolled economic growth was causing irreparable damage to the ecosystems and that these damages, at medium and long terms, should turn earth uninhabitable to humans [2]. 
To study this situation, the United Nations - UN promoted the debate of environmental issues, and designed Prime Minister of Norway, Gro Harlem Brundtland, head of the World Commission on Environment and Development, to study this theme. As result of this labor, it was presented a report entitled "Our Common Future", which established the concept of Sustainable Development, based on three pillars: economic growth, social equity and environmental balance [3]. This report was the basis for discussions of the United Nations Conference on Environment and Development, known as RIO-92 or ECO-92, thus allowing the creation of Agenda 21: Global Sustainable Development [1].

The evolution of environmental issues brought to discusson a new variable: sustainability. This requires a strong reflection in trying to understand the new reality, providing a paradigm shift. Since then, it was tried to integrate socially responsible practices, environmentally sound, traditional techniques associated with the production and management of the industrial sector, given the aim of society to consume products free from wastes and harmful effects to the environment. According to the United Nations, which used demographic estimates, the world population reached the milestone of 7 billion people in 2012. This means, among other necessary steps, that, for humans live harmoniously, it is imperative to establish public policies for solid waste management and deployment of an effective management system.

\section{Objective}

The objective of this study is to perform a critical analysis of the current Integrated Solid Waste System in the city of Santos presented by the municipal authority in 2011 , focusing on hazardous waste, identifying opportunities for improvement.

\section{Contextualization and Methodology}

The city of Santos, founded in January, 26, 1546, has written in its flag "Patriam Charitatem et Libertatem Docvi". It is a port city, head of the Santos Metropolitan Region, located on the coast of São Paulo state, Brazil. It houses the largest port in Latin America, which is primarily responsible for the economic dynamics of the city, together with tourism, fisheries and trade. In 2010, the Santos municipality had 419,757 inhabitants, according to the census conducted in the country. The United Nations Program for Development of 2000 placed the city of Santos in sixth place in the list of municipalities by the human development index, and it is currently the 17th richest city in the country. With the discovery and explotation of pre-salt project (oil laying very deep under sea devel) by Petrobras (the chief Brazilian oil enterprise), the city of Santos will house the headquarters of the Business Unit Gas Exploration and Production of Oil in Santos Basin.This certainly implies strong growth in business and commercial activities in the city, with its repercussions on the sustainability problem. 
A case study conducted by the authors to evaluate the Integrated Management System of Solid Waste in the city of Santos approved in 2011, proposed by the Department of the Environment, on the subject of waste management hazards, especially fluorescent lamps, batteries, junk and X-ray slides, presents a systemic approach to evaluate the ability to manage the entire process as a system, identifying and understanding the network of processes and their interactions. Hazardous wastes have characteristics of flammability, corrosivity, reactivity, toxicity, pathogenicity, carcinogenicity, mutagenicity and teratogenicity, presenting a significant risk to public health [4]. The aim of the project is to classify the responsibilities for achieving results, reducing barriers to better integration between the interested actors, in accordance with the principles of Quality Management.Therefore, in the case study, were heard governances representing the sectors of the residential and commercial buildings, and retail trade in Santos, represented by the presidents of its representative entities, by applying a structured questionnaire based on three pillars: environmental Education for the population, Infrastructure and Communication System offered by the municipal authority.

\section{$4 \quad$ Theoretical Background}

This study is based on developing a critical analysis of the Plan of Integrated Solid Waste Management in the Municipality of Santos in 2012, aiming to get compliance with the National Policy on Solid Waste Plan of 2010 and the Basic Guidelines of Sanitation of 2007 [5]. Solid waste or garbage are the remains of human activity, considered by generators as useless. This waste is classified into three categories: hazardous, non-inert and inert [6].

The integrated management of municipal waste is a coordinated set of regulatory actions, operational and financial planning, based on environmental and economic health criteria, to collect, segregate, treat and dispose the garbage in the city. Moreover, the municipal authorities are key pieces in the integrated management of municipal waste. They not only have the responsibility for implementing actions that aim to mitigate their effects, but also that of educating citizens, technicians and planners for this urgent need [4].

It is estimated that the world population produces around 40 million tons of waste per year. Society requires the transformation of natural resources into products to benefit their needs in general. These products, when they reach the purposes for which they were created, ie, the end of its useful life, are discarded. This whole process eventually leads to the deterioration of the natural environment, because the amount of solid waste produced by society is unquestionably one of the sources of environmental degradation [7]. To address this situation, from the 1980s the theme "reverse logistics" was explored with greater intensity at the academic, public and corporate levels, aligned with the philosophy advocated by the planet's sustainable development presented by the World Commission on Environment and Development. In the 1990s, some world-renowned authors conceptualized reverse logistics as a "new area of business logistics, concerned to consider the multitude of logistical 
aspects of the return to the productive cycle of the different types of industrial goods made of these materials and waste industrial controlled by reuse of the well and its components or recycling of the constituent materials, giving rise to secondary raw materials which reintegrate the production process" [8].

The world changes at every moment. New products are launched in the market to meet the needs of people. This requires advanced technology and the use of natural resources. Consequently, the mindset of the consumer also changes in this process, because it requires changes in production processes and a new stance on ethics and social responsibility. Having a properly socially responsible business is a requirement of the current market. To be effective, this vision must be structured in the long term, ensuring benefits for future generations. In 1987, John Elkington proposed a management model known as "Triple Bottom Line", by which, the entire business management should be based on economic, social and environmental issues [7]. For these actions to be effective, it is imperative to have a change in the mindset of people and, therefore, of the population. For this, two actions are essential: Education and Communication. Corroborating this idea, the authors refer to the $13^{\text {th }}$ Deming point "Institute a strong program of education and self-improvement." According to this outstanding master on quality, training and self-development are important means for continuous improvement of people, both from the professional and personal standpoint [9]. Translating this point to a system for environmental management, environmental education is a very complex issue because, when dealing with a population, there is a great diversity in the level of knowledge and discernment in matters relating to the environment [10].

On the other hand, a communication strategy is an essential part in the analysis of the life cycle of a product, based on the inventory of generates waste, since it directs to population the communication efforts related to the categories of impact and its main social and ambiental effects.

\section{$5 \quad$ Method of Control}

For this study, the PDCA cycle was customised fot better evaluate the Integrated Solid Waste System in the city of Santos, as shown in Figure 1 prepared by the authors.

The success of any management plan lies in the managers' ability of how to identify and solve problems. World Class Organizations have expertise in knowing how to apply the PDCA (Plan - Do - Check - Act) cycle throughout the organization. The PDCA cycle seems simple at first glance, and, in fact, is simple. However, those who use this method intensively over the years realize that, the more it is used throughout the organization, the more it is seen its complexity. This method allows: greater involvement of people, commonality of language and communication, understanding of each responsibility for the success of the system, continuous learning, use of several areas of science and uptake of best practices [11]. Moreover, a communication strategy is a key part of the analysis of the life cycle of a product, based on the inventory of waste generated, for directing the communications efforts 


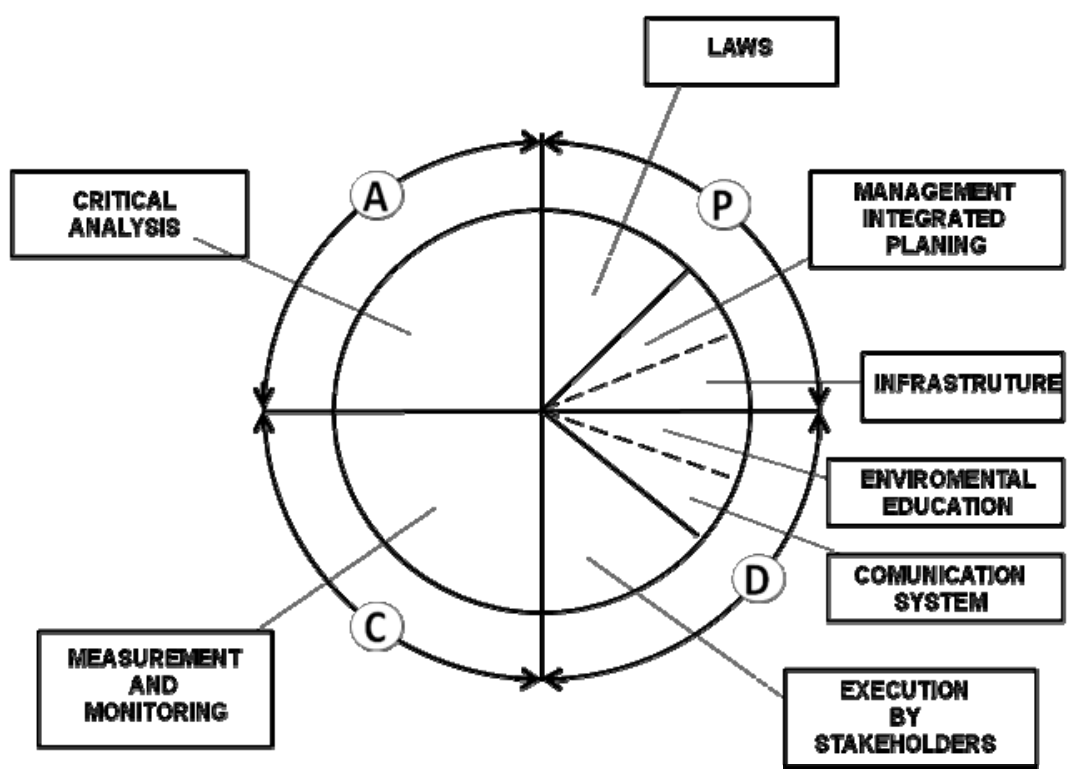

Fig. 1. PDCA cycle adapted to the Integrated Solid Waste System

throughout the organization, the more it is seen its complexity. This method allows: greater involvement of people, commonality of language and communication, understanding of each responsibility for the success of the system, continuous learning, use of several areas of science and uptake of best practices [11]. Moreover, a communication strategy is a key part of the analysis of the life cycle of a product, based on the inventory of waste generated, for directing the communications efforts for the population towards to the selection of impact categories and its main social and environmental impacts.

\section{Discussion and Results}

To comply with the National Policy on Solid Waste, 2010, the Department of Environment has developed the Integrated Management Plan based on the environmental management system established by ISO 14001:2004, with the control method of PDCA. Four grate goals were established in order to develop the integrated management: promoting the feasibility of reverse logistics flows to the waste generated in the municipality, expansion of discussion within the Metropolitan Agency in relation to waste management, development of contingency and emergency plans, and specific amplification of selective waste, deployed for each type.

The document is structured with an introduction by addressing the physical, economic and social aspects, a diagnosis contemplating an inventory of each type of waste and oversight responsibilities, goals for the integrated management, alternative use of reverse logistics for reuse or purification on of waste, investment proposals, operational environmental performance indicators, corrective and preventive actions 
to be practiced, contingency actions, environmental education programs and technical training, social communication and periodicity of quadrennial review.

The diagnosis for hazardous waste from the health sector is quite detailed, but for the waste under study is very superficial. The author have observed the absence of a guiding schedule of actions, thus existing the risk of becoming a "letter of intention".

In order to straiten the critical analysis, there ware elaborated three questions and applied to the society representatives mentioned in contextualization and methodology:

1. How fo you evaluate the present Environment Education Program offered by the municipal authority to the population?

2. The communication system used by the municipal authority to inform population about the correct storage and disposal of dangerous waste is clear and objective?

3. The present infrastructure of reception and destination of dangerous waste in the city of Santos is adequate from the viewpoint of the reduction of Effects to environment?

The participants agreed in affirming that the topics referred to the issues Ambiental Education to the population, Communication System and Infrastructure offered by the municipal authority are rather week and discorected from society, what is worrying and must be improved.

It is not clear the system to collect hazardous waste among the population under study. However there are several companies with their efforts to capture and destination waste within their social responsibility programs.

Nevertheless, the structure proposed by the municipal authority was considered potentiality good and, if put in action as planned, have a nice probability of success to protect environment. However, the analysis of the indicators proposed in the plan shows lacks, what may make impossible the renement of the waste inventory for adequate mitigation.

The Integrated Solid Waste in the city of Santos, novelty implemented by the municipality, contributes to improve the quality of life of the population. The system is classified as level 2 (limited information or little understanding of the objectives of the improvements required, some good results available), according to the description of maturity levels established by ISO 10014:2006 - Quality management -Guidelines for realizing financial and economic benefits, focusing on the Principle of Quality "System approach to management"[12].

\section{Conclusions}

Public sector has a peculiar quality management focused on the establishment of laws, ordinances and inspections. However, this is not enough from the perspective of modern management in the XXI century. The examined plan is not conclusive for the correct identification of the problems, which shell inevitably contribute to the low productivity of the system. 
Therefore, the authors propose to strengthen the systems approach to management, the adoption of the Theory of Constraints by Eliyahu M. Goldratt, which is a systemic management philosophy, based on the application of principles and methods of human organizations to Exact Sciences[13].

It is fundamental the development efforts for an effective management practice through the PDCA model considering the opportunities of improvement identified by the society representative governance. PDCA cycle has become a universal management concept, a true legacy, a tool whose owner is humanity in the service of identifying and solving problems that are present in the globalized society.

\section{References}

1. Melo, M.A.: e-Government Portal, digital inclusion and the knowledge society (May 29, 2012), http: / /www. egov.ufsc.br/portal/conteudo/

o-desenvolvimento-industrial-e-o-impacto-no-meio-ambiente (access in: February 17, 2013)

2. Werner, E.D.M., Bacaraji, A.G., Hall, R.J.: Cleaner production: methodological concepts and definitions. In: Symposium on Excellence in Management and Technology. [S.l.] (2011)

3. ONU. Our common future. Rio de Janeiro: Fundação Getúlio Vargas (1991); Pereira, A.L., et al.: Reverse logistics and sustainability. Cengage Learning, [S.1.] (2012)

4. IPT. Municipal waste: Integrated Management Manual. Institute for Technological Research, São Paulo (1995)

5. SEMAN. Integrated management plan of solid waste in the city of Santos. Prefeitura Municipal de Santos. Santos (2012)

6. ABNT. NBR 1004 - Solid waste classification. Brazilian Association of Technical Standards, [S.1.] (1987)

7. Rao, D.F., et al.: Reverse logistics-Conceits and system components. XXII- National Meeting of Production Engineering. [S.1.]: [s.n.] (2002)

8. Pereira, A. L., et al.: Reverse logistics and sustainability. Cengage Learning, [S.1.] (2012)

9. Gitlow, H.S.: Planning for quality, productivity and competitive position. Dow JonesIrwin, [S.1.] (1990)

10. Falconi, V.: The true power. Belo Horizonte: Management Development Institute (2009)

11. Amato Neto, J.: Production \& Sustainability. Atlas, São Paulo (2011)

12. ISO. ISO 10014- Quality management- Guidelines for realizing finanial and economic benefits. International Organization for Standarzation. Genebre (2006)

13. Cox, J., Spencer, M.: Theory of Constraints Handbook. Reichmann and Affonso Editors, São Paulo (2000) 